\title{
Research on the Local Construction of Innovative Lingnan Cultural Tourism Town From the Perspective of Cultural Gene
}

\author{
JingYang $\operatorname{Lin}^{1}$, QingKun $\mathrm{Du}^{1}$ and $\mathrm{Wei} \mathrm{Bi}^{1 *}$ \\ ${ }^{1}$ School of Art and Design, Guangdong University of Finance and Economics, Guangzhou City, Guangdong \\ Province, China \\ ${ }^{1 *}$ Corresponding author's e-mail: Wei Bi. Guangdong University of Finance and Economics.35290984@ qq.com
}

\begin{abstract}
Nowadays, cultural tourism town faces the problems of culture conceptualization, industry homogenization and unitary industrial structure. In response to this, the thesis aims to bring forward an innovative approach to build the Lingnan Cultural Tourism Town. Taking the Lingnan region as an example and under the perspective of cultural genes, the thesis analyzes and classifies the regional cultural genes, makes a pedigree map on them, refines and transforms the core element thus to build a cultural tourism town from these three aspects: macro-guidance, meso-control and micro-implementation, and to innovate the building and application of Lingnan Cultural Tourism Town. As a result, a development framework for innovative cultural tourism town based on core cultural genes are completed. The cultural tourism town are energized and innovated and finally the sustainable development of regional culture is attained. The core of building innovative cultural tourism towns is to sort out cultural genes, complete the transformation from cultural resources to cultural values, apply them in the construction of cultural tourism towns. At last, it will make the towns more competitive and realize sustainable development for regional culture.
\end{abstract}

Keywords: Cultural gene, Cultural tourism characteristic town, Innovative cultural tourism town, Regional culture.

\section{INTRODUCTION}

In September, 2020, the National Development and Reform Commission issued the "Comments on Promoting the Standardized and Healthy Development of Characteristic Towns". As an important medium to bridge the development gap between different cities in China and advance urbanization, the characteristic towns have entered a new era of high-quality development. Speeding up the process of building characteristic towns not only plays an important role in the transformation and upgrading of China's social economy, but also an important way to reach the goal of "basically realize socialist modernization". Characteristic towns are mainly divided into three categories, namely cultural tourism, community, and industry. Cultural tourism towns account for a relatively large proportion of the construction of characteristic towns, whose pillar industries are culture with regional features and leisure tourism. They've met the need of the market and developed rapidly. Culture with regional features is the core of cultural tourism towns, which emphasize the exploration and refinement of regional culture, cultural genes' combination with the town's leading industries, style construction and spatial planning, as well as building an innovative cultural tourism towns on the ground.

From the current status of some cultural tourism towns, it can be found that the construction is still in the early stage of development, lacking overall consideration, and facing several key problems as follows.

\subsection{Cultural conceptualization}

The generalization of the concept of cultural tourism towns is relatively common. First of all, it can be manifested in the rigid combination of industrial or cultural characteristic towns with tourism, which lacks thinking in the whole pattern. Secondly, the planned concept of cultural tourism towns is similar, and the lack of thinking about themes has led to a board positioning. 
Finally, the attention paid to the original ecological style and regional features of the town is insufficient, and some cultural gene even lost its connotation.

\subsection{Industry Homogenization}

Most cultural tourism towns are alike in planning and construction, such as similar theme of the towns, generalization of cultural products without one's own characteristics, as well as the lack of special business model.

\subsection{Unitary Industrial Structure}

The industries in characteristic towns have little connection with its regional culture. The tourism product is unitary. And there is a lack of mutual consultation and joint construction among different industries, resulting in the independence of each other in terms of positioning and operation.

The core of the three issues above lies in taking into account the connotation of culture with regional features. How to explore the cultural genes and combine them with characteristic resource industries, and realize a coordinated development are the focus of building innovative cultural tourism towns. Based on the summary of the key issues, this thesis is carried out from the perspective of culture genes. It takes the Lingnan region as an example, extracts core cultural genes and applies them in the building of innotive cultural tourism towns through the construction of a cultural gene pedigree map. In this way, the town is revitalized and become innovative, and finally realizes the sustainable development of Lingnan culture (Figure $1)$.

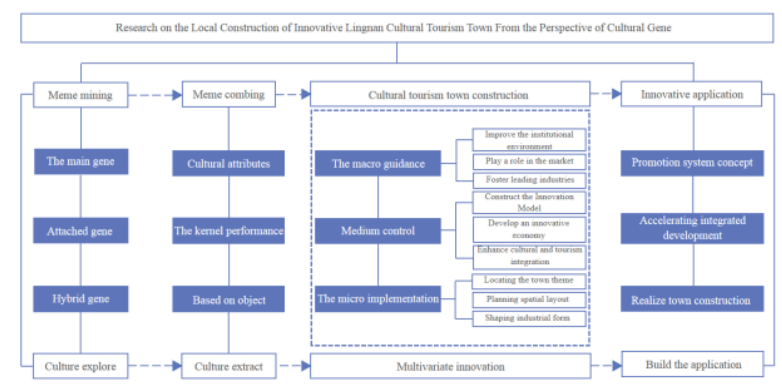

Fig.1.Overall research framework.

\section{EXPLORING CULTURAL GENES, TRANSFORMING AND APPLYING INTO TOWN CONSTRUCTION}

Cultural genes are the basic elements cultural system and are used to study cultural transmission and evolution. The "Classified Dictionary of the Essence of Chinese Culture" explains that culture is mainly composed of three genes: culture of social system, spiritual culture and material culture. First, the culture of social system is the main one in the cultural gene, which generally refers to the experience accumulated by human beings in the process of continuous improvement. Secondly, the spiritual culture, an attached gene, usually refers to the spiritual and moral subjective consciousness of human beings in the process of transforming themselves. Lastly, material culture, also known as physical culture, is the mixed gene, which refers to the artifacts, technologies and other objective things that humans acquired through processing. Therefore, when analyzing Lingnan cultural genes, we should pay attention to the relationship between the three genes, and sort out the characteristic culture according to the corresponding level.

\subsection{Construction of the Pedigree Chart of Lingnan Cultural Genes}

The pedigree chart of Lingnan cultural genes, mainly including three elements, cultural attributes, core manifestation, and basic objects, deconstructs and rearranges according to different attributes and internal logical relationships. In this way, a pedigree chart that completely records all the information of Lingnan culture is formed. Lingnan, located in the lower reaches of the river and backed by the mainland, is far away from the Central Plains in China. It is a typical marine culture that values business interests and emphasizes development both internally and externally. Lingnan culture has a long history covering art, architecture, religion, food, language and other fields. With its distinctive characteristics of diversified innovation, openness and compatibility, it has had an important influence on the culture of the Chinese nation. Based on a large number of research materials relevant to the culture and history of Lingnan and field investigations, this thesis focuses on the local culture, and conducts an in-depth analysis of its cultural genes from the territory, architecture, production, humanity and so on. Also, it attempts to make a pedigree chart of Lingnan cultural genes (Figure 2) based on the three different gene classifications: main gene, attached gene and mixed gene, which makes it more convenient and clear to show the content, characteristics and interrelationship of Lingnan culture gene.

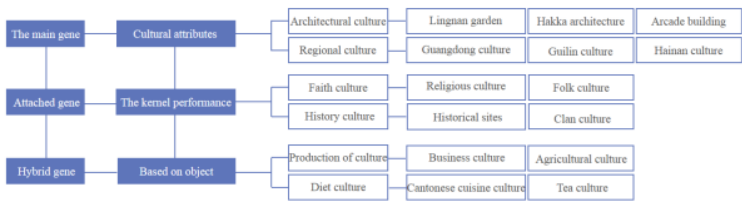

Fig.2.Genealogy legend of Lingnan culture gene.

\subsection{Sorting Out The Core Gene Path of Lingnan Culture}

The making of a cultural gene pedigree chart is like 
taking the DNA chain of biomolecules as a carrier, and the cultural system heritage information on the chain is replaced, reshaped or even mutated so as to spread and improve these information[1]. Since there are differences in the functional types of cultural genes in the pedigree diagram, the design factor extraction method of product design will be adopted in the study of inheritance path. And the core genes of Lingnan culture will be extracted by the following path according to the principle of specific classification of cultural genes (Figure 3):

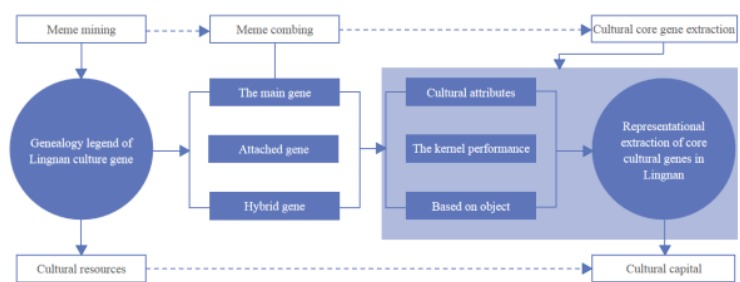

Fig.3.Legend of concrete extraction path of Lingnan core cultural gene.

\subsubsection{Exploring The Main Genes Based On Geographic Dominance}

The main gene is the matrix of the cultural gene pedigree, whose main function is to dominate cultural attributes and ensure cultural diversity. It is a cultural gene with a large influence. The inheritance path of the main gene should be based on the cultural strategy grafting to realize the sustainable development of regional culture.

\subsubsection{Extracting Attached Gene Under The Adaptability Principle}

Attached genes are attached to the main gene and are usually presented obviously, which can be identified with certain carriers of regional culture and other culture are easy to implant. Therefore, the inheritance path will focus on extracting cultural symbols and implanting them into cultural spaces and products, so that visitors may have a sense of regional cultural belonging.

\subsubsection{Finding The Mixed Genes Following The Principle of Integrity}

Mixed genes are generally not unique to a certain region, but they recorded the cultural genes of Lingnan in a specific historical period. Therefore, protection should be the main inheritance path, among which the living inheritance of material and spiritual connotations should be paid attention to.

\subsection{Concrete Extraction Of Core Genes Of Lingnan Culture}

Through the construction of the pedigree chart of cultural genes and the extraction of core cultural genes earlier, the concrete core genes of culture are extracted from the three aspects of cultural attributes, core manifestations and basic objects. First, cultural attributes mainly include architectural cultural genes (Lingnan gardens, Hakka architecture, arcade architecture) and regional cultural genes (Guangdong culture, Gui culture, Hainan culture). Second, the core manifestations are belief culture genes (religious culture, folk culture) and historical cultural genes (historical relics, clan culture). Third, basic objects involve production cultural genes (commercial culture, agricultural culture) and dietary culture genes (Cantonese cuisine culture, tea drinking culture). Through these three levels of classification and extraction, multiple core cultural gene elements can be attained for the local construction of the innovative Lingnan cultural tourism town.

\section{BUILDING INNOVATIVE CULTURAL TOURISM TOWNS BY ENERGIZING, INNOVATION AND UTILIZATION}

\subsection{Apply Macro Guidance to Promote Systematic Design}

\subsubsection{Improve Institutional Environment and Support With Relative Policy}

As an important part of the current construction of towns with Lingnan features, the government, on the one hand, have to determine the leading industry for town development, decide on the direction and content of construction and development, and build a new industrial ecosystem. On the other hand, it is necessary to coordinate industrial development and urban construction, and provide policy support, including: (1) Providing Industrial land support: fully consider the needs of small town industrial development and provide certain land support. (2) Setting relevant standards: play out the cultural advantages of Lingnan, and to promote the development and operation of innovative cultural tourism towns under relative rules and regulations. Building a standardized town, and achieve innovative development. (3) Strengthening industry guidance with policies: provide relevant guidance to Lingnan cultural and tourism industry chain, and ensure the connection between technology and industry.

\subsubsection{Give Full Play To The Market And Optimize Industrial Structure}

In addition to the influence of government systems and policies, market demand is also an important factor affecting the development direction of Lingnan cultural tourism towns. Market demand determines whether the industry can survive or thrive. If the market cannot 
provide enough space for the flexible construction of the town industry, the development of the leading industry will be limited, which will affect the overall town building. The industrial structure of cultural tourism towns is inseparable from both the government's macro-control and the market mechanism. The government's macro-control guides, adjusts, and even supervises the industry, while the market mechanism optimizes its structure and play a decisive role in its core.

\subsubsection{Foster Leading Industries and Give Full Play To Competitive Advantages}

At present, China's cultural tourism town industry is still in the early stages of development, facing some problems such as imperfect industrial structure, inaccurate market positioning, and unclear leading industries. The study of industrial economics provides reference standards for determining the leading industry in characteristic towns. On one hand, it starts from income elasticity, consider the industry of cultural tourism town from the demand side, analyze the relationship between industrial demand and regional economic growth, and determine the direction of the industrial structure. On the other hand, it focuses on the linkage effect, sorting out the relationship between the industrial chains of cultural tourism town, determining the leading industries that promote related industries, thus leading to industrial agglomeration, and giving full play to the competitive advantages of Lingnan cultural tourism towns.

\subsection{Apply Meso-control To Accelerate Integrated Development}

\subsubsection{Build An Innovative Model And Foster Industrial Clusters}

In the process of building cultural tourism towns, it's necessary not only to have a scientific regional planning and reasonable industrial structure, but also the practical guidance for the subsequent development of the town. The core of creating an innovative model is taking the market as main operating entity, and the government should avoid over-functioning. This can better handle the relationship between the market and the government so that they can produce a larger effect. The industrial model of cultural tourism town is changeable. Multiple forces, from the foster of leading industry to the integration of industries relating to cultural tourism, should be gathered to form industrial clusters. Attract customers based on the town's positioning and its theme. Besides, the government should build a digital platform for industry cluster with the help of big data and make the Internet of Things to become a driving force for the future sustainable development of the town.

\subsubsection{Build An Innovative Economy And Foster Diversified Development}

Currently the business operation of characteristic towns are almost the same. In view of this, this thesis proposes a new path for innovative development, in order to cultivate the diversified development of the town. Regarding the sustainable operation of cultural tourism towns, we should fully comply with economic laws and develop an inclusive and innovative economy, including: (1) Focus on the current consumption hotspots and foster business types that adapt to it, promote the operations of innovative cultural tourism towns based on different cultural genes in the region. (2) Strengthen the application of digital information technology, build a small town platform, improve services like business operations, service reservations, etc., and keep in line with the times on the existing basis. (3) Introduce financial services to guarantee the funds that need of development and construction funding. Recruit partners for potential programme to ensure financial support and strengthen management, and avoid operating risks.

\subsubsection{Strengthen Culture And Tourism Integration To Achieve Overall Coordination}

Cultural and tourism integration is an important concept for the development and transformation of innovative cultural tourism towns. As a systematic concept, the integration covers five major aspects: (1) Institutional integration: Integrate tourism and cultural knowledge and make them dependent on each other. (2) Site integration: Integrating visiting and experiencing elements and transform the town into a travel place, which offer platform for the culture. (3) Business integration: Integrate development factors and industry, and tourism industry should be linked to cultural development. So as to form a new driving force for cultural tourism consumption. (4) Product integration: Products are the main manifestation to integration of cultural and tourism integration. Therefore, it is necessary to produce high-quality cultural tourism products and form a good product system. (5) Management integration: Strengthen the cultural industry ideology and tourism industry market value, and improve the integration of cultural tourism and management. The purpose of "promoting tourism with culture and spreading culture with tourism" is to promote the feature and vitality of the town, and achieve overall coordination for the town development. 


\subsection{Apply Micro-implementation To Construct The Small Towns}

\subsubsection{Positioning The Theme Of The Town And Promote Its Transformation And Upgrading}

Through sorting out the cultural genes in Lingnan region and extracting the core cultural genes before, we may get the position by its features and advantages, needs for self-development,and by combining various development needs. Classify the characteristic cultural resources then integrate then from different dimensions, and accurately position the theme of Lingnan cultural tourism town: based on an open commodity economy, it operates through integration and exchange with rich cultural as the development form. Centered on the three strategies of "big culture, big industry, and big data" in Lingnan and with the help of new information industry clusters and green ecology, it aim to upgrade the core of traditional cultural tourism development, build an industrial platform and expand the innovative economy. So as to realize the transformation and upgrading from "Lingnan traditional cultural tourism town" to "Innovative cultural tourism town with Lingnan features".(Figure 4)

\section{Lingnan traditional cultural touris
characteristic town}
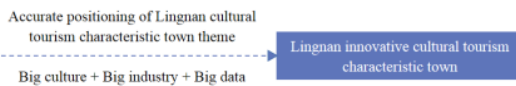

Fig.4.Schematic diagram of Lingnan innovative cultural tourism characteristic town positioning.

\subsubsection{Planning The Spatial Layout And Focusing On Environmental Construction}

The space of Lingnan cultural tourism town need to pay attention to regional linkage. For example, some traditional regional buildings, such as arcade buildings and Lingnan gardens, should be protected and repaired according to local conditions. The new areas should focus on highlighting the local features on the basis of overall planning, combining some Lingnan regional cultural symbols, such as arcade architectural symbols, Canton carved sculpture symbols, etc., into the modern construction, and building cultural tourism towns that is ecologically localized and universal. Lingnan cultural tourism industry is the core of building innovative cultural tourism towns. Therefore, the model of regional layout, "core cultural industry + tourism + attached driving mechanism" should be considered in the spatial layout planning, and the urban spatial layout should be planned from the overall perspective. Introduce the scenery to highlight the spatial features of the town, systematically integrate and manage the town's regional characteristics, plan the overall layout according to diversified collection and layout of the four parts of functional node system[2], and establish a promotion model that centers on the Lingnan multicultural industry field with tourism service and culture-spreading as the connotation.(Figure 5)

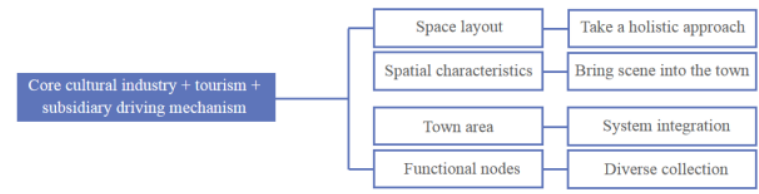

Fig.5.Legend of spatial planning and layout of Lingnan innovative cultural tourism characteristic town.

\subsubsection{Shaping The Industrial Form And Driving The Mechanism Reform}

After constructing the gene pedigree chart of Lingnan culture, it can be concluded that the main genes of Lingnan culture is multicultural. We may combine the local endowment, resources and features, put forward the concept of "Lingnan Man Mu", which reflects the diversity of Lingnan industry. And that can be used for designing cultural and creative products and carrying out cultural tourism activities, as well as expanding local culture, local business forms in order to foster more industries and helping the tourists have a better experience when visiting the town. At the same time, based on cultural tourism and with industrial clusters as system, we may create a model for building the Lingnan innovative cultural tourism town. By precise positioning, visualized application, and intelligent overall planning, the construction of a cultural tourism town, featuring "modern cultural tourism industry + information data [3]. platform + intelligent IoT network", can be realized. Different from the general cultural tourism towns in the industrial spatial layout, its layout is of diversified industrial branches. A big data center for smart cultural tourism town industry is founded, which may be extended to a vertical industrial ecosystem, to comply with the structural changes on the industrial supply side, and to drive the mechanism reform of the town. Then, smart cultural tourism can be achieved.

\section{CONCLUSION}

The core of the local construction of the Lingnan innovative cultural tourism town is to explore, analyze, transform and apply the culture with regional features. Taking the Lingnan region as an example, this thesis attempts to explore and sort out the local cultural context from the perspective of cultural genes, extract core cultural genes through the making of cultural gene pedigree chart, and realize the transformation from cultural resources into cultural capital. It chooses the appropriate path for development according to different attributes and corresponds to the macro-, meso- and micro-level. And finally, the thesis combines the principles of development in the new era to achieve a deep integration of culture and tourism in Lingnan, 
providing feasible ideas for the sustainable development of local culture and industries, thereby completing the local construction of innovative cultural tourism town.

\section{ACKNOWLEDGMENTS}

This paper is one of the stage results of the research on innovative cultural tourism design of Lingnan red cultural resources, a longitudinal project of Guangdong universities' scientific research project in 2019. Authors here acknowledging assistance or encouragement from colleagues, special work by technical staff and financial support from organizations.

\section{REFERENCES}

[1] H. Zhao, J. Wang, Z. Yuan, T. Ma. Genealogy Construction and Inheritance Path of Cultural Genes -- Taking Ancient Dian Culture Genes as an Example. Modern Urban Studies, CN, 32-1612/TU, (05), 90-97, (2014)

[2] J. Qiu, H. Wang. Developing with Culture: Research on the Construction Path of Tourism Characteristic Town in the Era of Cultural and Tourism Integration. Commercial Economy, CN, 23-1057/F, (06), 63-64+93, (2019)

[3] Y. Fang, W. Yi, W. Huang. Study on the development path of characteristic towns in Guangdong Province from the perspective of industrial upgrading. Economic $\mathrm{BBS}, \mathrm{CN}$, 13-1022/F, (01), 73-77, (2019)

[4] L. Gong. Cultural and tourism integration development path innovation of characteristic towns. Guangdong Silk, CN, 44-1319/S, (04), 123-124+146, (2020) 